\title{
JUURNAL.RU
}

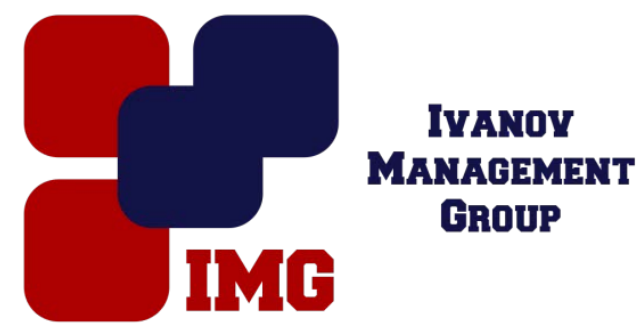

Добрынин А.C. Томский государственный университет систем управления и радиоэлектроники Томск, Россия

doi: 10.18411/lj-31-10-2016-3-03

idsp 000001:lj-31-10-2016-3-03

\section{Проявление инерционных тенденций в развитии физической культуры и спорта в регионе}

Приоритетность вопросов развития физической культуры и спорта закреплена на государственном уровне в стратегии социально-экономического развития Российской Федерации. Приняты законодательные и организационные решения, предусматривающие последовательное увеличение (до 2020 года) доли граждан, систематически занимающихся физической культурой и спортом. Однако, следует учитывать, что спорт - это система, подверженная влиянию тех же механизмов, что и вся экономика в целом. Тенденции, актуальные в современной экономическо-социальной сфере отражаются и на развитии спорта. Ситуация в экономике, складывающаяся под влиянием стагнации, введения экономических санкций со стороны запада, понижение курса рубля и своеобразная изолированность России в мировом сообществе неотвратимо влияют на состояние спортивной сферы в целом.

Казалось бы, сфера спорта - это яркие и зрелищные мероприятия, радость от эффектных побед и грандиозных спортивных событий, однако это лишь верхушка айсберга, за которой стоит механизм, подверженный тем же рискам, что и любая система, тесно связанная с экономикой. [1]

Сфера спорта пережила вместе с экономикой страны спад, но в последнем десятилетии страна взяла курс на улучшение условий массового спорта и мощное развитие спорта высших достижений. Страна не раз доказывала, что способна в кратчайшие сроки организовать и провести на высшем уровне 
международные соревнования. Принятие программы развития спорта на 20062015 года стало в свое время мощным толчком к выходу из кризиса в данной сфере. В настоящее время её реализация завершена, однако о видимых результатах говорить пока рано. Спорт не может существовать в отрыве от экономической и социальной сферы. Ситуация во внешней политике влияет на процессы в сфере спорта, как очевидно (из-за повышения курса валюты многие объекты спортивной инфраструктуры становятся не рентабельными, рост цен приводит к невозможности занятием спортом социально не защищённых слоёв населения и т.п.), так и косвенно, например, попытки государства субсидировать массовый спорт, детский спорт зачастую связаны с ростом бюрократических механизмов, недоработаностью нормативной базы. В этом противоречии проявляются некоторые инерционные тенденции, действующие и в сфере спорта. Инерция - свойство, присущее всем системам, в том числе и социальноэкономическим. В научный оборот инерция введена, как определенная абстракция для отражения свойства материи сохранять устойчивое, равномерное движение в результате отсутствия или уравновешивания внешних воздействий. Социально-экономическую инерцию, тем не менее, нельзя сводить к устойчивости. Она выступает тождеством противоположностей: изменчивости и устойчивости.[2]

Для решения существующих в сфере спорта проблем крайне важно учитывать перспективы и долгосрочность последствий развития этой сферы в рамках концепции инерции. Речь идет о том, что необходимо обозначить факторы и явления, препятствующие развитию спортивной сферы.

В современных условиях, можно назвать следующие следствия проявления инерционных тенденций:

- отсутствие развитой инфраструктуры между ступенями развития спортсмена от детского спорта к профессиональному;

- -бессистемное, точечное инвестирование средств в отдельные виды спорта; отсутствие комплексного подхода к составляющим успеха в профессиональном спорте - медицина, биология, технологии спорта;

- подверженность детского спорта колебанию цен и снижению его доступности.[3] 
Рассматривая сложность ситуации в развитии спортивной сферы на ближайшие годы в контексте общей экономической ситуации следует учитывать дальнейшие перспективы ухудшения условий развития спорта, снижение темпов роста показателей, свидетельствующих о достижениях в спортивной сфере.

Поэтому назрела необходимость формирования и внедрения новой модели управления спортом в РФ, которая призвана нивелировать противоречия, создавать условия для развития всех направлений физической культуры и спорта, для роста спортивных показателей, не допускать инерции спада в результате роста одних элементов сферы за счёт других. Например, не должно быть дорогостоящих контрактов с тренерами и спортсменами при недостаточных условиях для воспитания собственных спортсменов и менеджеров высочайшего уровня, поддержки только спорта высших достижений в отрыве от развития детских спортивных секций. Основой новой модели управления, как фактор ухода от инерционных тенденций, может стать акцент на использование внутренних сил для самоорганизации и саморегуляции системы спорта, выявление новых потенциальных возможностей и формирование условий для ее развития. 


\section{Литература}

1. Предпосылки преодоления инерции регионального экономического развития в условиях санкционной политики и ресурсных ограничений [Электронный ресурс] - URL: http://www.publishing-vak.ru/file/archiveeconomy-2015-1/3-afonasova.pdf (дата обращения: 29.06.16)

2. Инерционность как свойство экономического развития городов традиционно-промышленного региона [Электронный ресурс] - URL: http:/upravlenets.usue.ru/images/51/14.pdf (дата обращения: 29.06.16)

3. Экономика и управление в сфере услуг [Электронный ресурс] URL:http://www.m-economy.ru/art.php?nArtId=2783(дата обращения: 29.06.16) 